\title{
PERTUMBUHAN SENGON DAN PRODUKSI PADI GOGO PADA TARAF PEMUPUKAN P YANG BERBEDA DALAM SISTEM AGROFORESTRI
}

\author{
Growth of Sengon and Production of Upland Rice and Different P Fertilizers in Agroforestry System
}

\author{
Derie Kusuma Budi Ningrum $^{1 *}$, Nurheni Wijayanto ${ }^{2}$, dan Arum Sekar Wulandari ${ }^{2}$
}

(Diterima Juni 2018/Disetujui Desember 2018)

\begin{abstract}
Agroforestry of upland rice (Oryza sativa L.) and sengon tree (Paraserianthes falcataria) could increase the growth of sengon trees; however, it would also increase the percentage of empty grain due to shade from the tree. Fertilization with $P$ is expected to increase plant height, grain weight and weight of straw of upland rice and growth of sengon tree. The aim of this research is to analyze the growth and production of sengon and upland rice with agroforestry and $P$ fertilizer application. Application in cultivation of upland rice using split-split plot design. The main plot is agroforestry and monoculture, subplot of Sintanur and Situ Bagendit varieties and split-split plot of $P$ fertilization consisting of 4 levels, namely: $P O=0 \mathrm{~g} /$ plant, $P 50=3 \mathrm{~g} /$ plant, $P 100=6 \mathrm{~g} /$ plant and $P 150=9 \mathrm{~g} /$ plant. The application of $P$ fertilizer showed that $P 100 \%$ had high production on Sintanur varieties with monoculture. Agroforestry system can increase the growth of sengon plants.
\end{abstract}

Key words: agroforestry, $P$ fertilizer, sengon, upland rice.

\section{PENDAHULUAN}

Agroforestri adalah sistem penggunaan lahan dan teknologi yang menggabungkan tanaman tahunan (pohon, belukar, palma, bambu) dengan tanaman semusim dengan atau tanpa ternak pada unit pengelolaan lahan (plot) yang sama pada waktu yang sama maupun secara sekuen (Van Noordwijk et al. 2016). Salah satu tegakan hutan yang dapat dimanfaatkan dalam sistem agroforestri adalah tegakan sengon. Pohon sengon memiliki karakteristik tajuk yang ringan sehingga lahan di bawah tegakan sengon mempunyai potensi untuk pengembangan tanaman pangan (Wijayanto \& Pratiwi 2011).

Hasil penelitian Khalif et al. (2014) menunjukkan bahwa penanaman sengon (Paraserianthes falcataria) dapat meningkatkan kualitas kesuburan tanah diindikasikan dari adanya peningkatan masukan bahan organik, kandungan bahan organik tanah, $\mathrm{N}$ total, serta $\mathrm{N}$ tersedia. Menurut penelitian Hartoyo (2014) rata-rata diameter sengon pada pola agroforestri sebesar 11.52 $\mathrm{cm}$ dan pola monokultur sebesar $13.29 \mathrm{~cm}$ dengan umur sengon 4 tahun. Meskipun demikian perbedaan pola tanam sengon tersebut tidak memberikan pengaruh nyata terhadap pertumbuhan (riap) diameter sengon yang telah diamati selama 3 bulan.

\footnotetext{
${ }^{1}$ Mahasiswa Pascasarjana PS Silvikultur Tropika, Fakultas Kehutanan IPB

* Penulis korespondensi:

e-mail: derie.ningrum@yahoo.co.id

${ }^{2}$ Staf Pengajar Dept. Silvikultur Fakultas Kehutanan IPB
}

Naungan dengan paranet berpengaruh nyata terhadap pertumbuhan padi gogo yang ditunjukkan dengan meningkatnya proporsi naungan, tinggi tanaman bertambah, semakin kecil luas daun dan semakin berkurang bahan kering (Las 1982 dalam Lautt 2003; Muladi 1986 dalam Junaedi 2001). Persentase gabah hampa semakin besar dengan makin tingginya tingkat naungan. Hal ini berkaitan dengan rendahnya intensitas cahaya yang diterima, sehingga fotosintat yang dihasilkan menjadi lebih kecil dan akan mempengaruhi bahwa proses pengisian biji (Santosa 2000).

Saragih (2005) menyatakan pemberian pupuk $\mathrm{P}$ mampu meningkatkan tinggi tanaman, bobot gabah dan bobot jerami padi dengan penanaman padi gogo (Oryza sativa L.). Semakin meningkat dosis pupuk $\mathrm{P}$ yang ditambahkan menyebabkan kenaikan berat gabah per rumpun. Apabila tanaman sudah memasuki fase generatif, sebagian besar P diimmobilisasi ke biji atau buah serta bagian generatif tanaman lainnya. Kadar $\mathrm{P}$ bagian-bagian generatif tanaman (biji) lebih tinggi dibandingkan dengan bagian-bagian tanaman lain (Winarso 2005).

Penanaman padi gogo secara agroforestri di bawah tegakan sengon dapat mempengaruhi pertumbuhan dan produksi tanaman padi gogo (jumlah anakan sedikit, gabah hampa semakin tinggi) akibat intensitas cahaya matahari yang rendah di kanopi padi. Tujuan penelitian ini adalah menganalisis pertumbuhan sengon dan menganalisis produksi padi gogo dengan varietas Sintanur dan Situ Bagendit serta taraf pemupukan P yang berbeda dalam sistem agroforestri. 


\section{METODE PENELITIAN}

\section{Waktu dan Tempat Penelitian}

Penelitian dilaksanakan pada bulan Agustus 2017 sampai Desember 2017 dalam tegakan sengon dengan jarak tanam 3 x $3 \mathrm{~m}$ dan umur 3 tahun dengan luas lahan sekitar $2500 \mathrm{~m}^{2}$ di Kecamatan Bintoro, Kabupaten Jember.

\section{Bahan dan Alat}

Bahan yang dibutuhkan dalam penelitian adalah benih padi gogo varietas lokal genotipe Situ Bagendit dan Sintanur dari Balai Besar Penelitian Tanaman, pupuk Urea, SP 36, KCl. Alat yang dibutuhkan pada penelitian ini yaitu: lux meter, termohigrometer, haga hypsometer.

\section{Prosedur Penelitian}

\section{Persiapan benih dan media tanam}

Benih yang digunakan pada penelitian adalah benih padi gogo varietas Sintanur dan Situ Bagendit diperoleh dari penakar benih cv.maya sari di Jember-Jawa Timur. Varietas padi gogo Sintanur ini memiliki umur panen 115-125 hari, dengan anakan produktif 16-20 batang. Potensi produksi yang dapat dihasilkan mencapai 7.0 ton/ha. Varietas padi gogo Situ Bagendit ini memiliki umur panen 110-120 hari dengan potensi yang dapat dihasilkan mencapai 5.0 ton/ha (Deptan 2008).

Pengolahan tanah dilakukan seminggu sebelum tanam dengan cara mencangkul agar tanah menjadi gembur, kemudian dibuat petak antara tegakan sengon berukuran $2 \times 2 \mathrm{~m}$ (Jarak pohon sengon adalah $3 \times 3$ m). Jarak tanam sengon dan padi gogo sekitar $50 \mathrm{~cm}$ dan jarak tanam antar padi gogo sekitar $25 \mathrm{~cm}$ x $25 \mathrm{~cm}$. Setiap petak terdapat 64 tanaman padi gogo dalam 1 interaksi pupuk $P$ dan 1 varietas/ 1 ulangan. Terdapat 10 sampel pohon sengon yang telah diukur baik dalam agroforestri maupun monokultur.

Penanaman, pemupukan, pengendalian organisme pengganggu tanaman (OPT), dan pemanenan

Benih direndam selama 1 jam dengan fungisida berbahan aktif isoprothiolane $400 \mathrm{~g} / \mathrm{l}(\mathrm{d} / \mathrm{h}$ diisopropil1, 3-ditiolan-2-ilidenemalonat: 400). Penanaman dilakukan secara tugal dengan kedalaman lubang 2-3 cm dan jumlah benih 5 butir per lubang (Fadiluddin 2009). Jarak tanam padi sekitar 25 × $25 \mathrm{~cm}$ (Putra 2011).

Pemupukan atau pemberian nutrisi kepada tanaman dengan memberi pupuk Urea sebagai pupuk dasar yang diberikan dosis pupuk $\mathrm{N}$ sebanyak $150 \mathrm{~kg}$ urea/ha yang diberikan 3 kali, yaitu $1 / 3$ bagian pada pada umur 15 hari, $1 / 3$ bagian pada stadia anakan (30-40 hari setelah sebar), $1 / 3$ bagian pada saat menjelang primordia (50-60 hari setelah sebar).Pupuk Fosfor (P) dan Kalium (K) diberikan 2 kali yaitu pada saat tanam dan berumur 45 hari setelah tanam dengan dosis 100-150 kg SP-36/ha dan $100 \mathrm{~kg} \mathrm{KCI} / \mathrm{ha}$ (BBPTP 2015). Pupuk urea, fosfor dan kalium diaplikasikan dengan cara dipendam dan berjarak $5 \mathrm{~cm}$ dari tanaman padi gogo. Pestisida dengan bahan aktif deltametrin $25 \mathrm{~g} / \mathrm{l}$. Penyemprotan dilakukan saat OPT menyerang tanaman padi gogo (Irpan 2011).

Pemanenan dilakukan saat tanaman padi mulai matang secara fisiologis, yaitu lebih dari $85 \%$ gabah telah menguning. Padi gogo matang pada kisaran usia 105-115 HST (Hafsyah 2000).

\section{Rancangan Penelitian}

\section{Bagian 1. Pertumbuhan sengon}

Pengamatan pertumbuhan sengon menggunakan rancangan acak lengkap (RAL) dengan 1 faktor yaitu pola tanam. Pola tanam tersebut memiliki 2 taraf yaitu agroforestri (tegakan sengon dan padi gogo) dan monokultur tegakan sengon.

\section{Bagian 2. Produksi padi gogo}

Pengamatan produksi padi gogo menggunakan rancangan petak-petak terbagi (Split-split plot) yang terdapat 3 faktor dengan pengacakan metode RAK yang dilakukan 5 kali ulangan. Faktor 1 (Petak utama) terdapat pola tanam $(\mathrm{T})$ terdiri dari : $\mathrm{T} 1=$ Pola tanam agroforestri (sengon dan padi gogo) jarak tanam sengon $3 \times 3 \mathrm{~m}^{2}, \mathrm{~T} 2$ = Pola tanam monokultur (tanaman padi gogo). Faktor 2 (Anak Petak) terdapat varietas padi gogo (V) terdiri dari : V1 = Varietas Situ Bagendit, V2 $=$ Varietas Sintanur. Faktor 3 (Anak-anak Petak) terdapat pupuk $\mathrm{P}(\mathrm{P})$ terdiri dari: $\mathrm{P} 0=0 \%(0 \mathrm{~g} \mathrm{SP}-$ 36/tanaman), $\mathrm{P} 1=50 \%$ (3 g SP-36/tanaman), $\mathrm{P} 2=$ $100 \%$ (6 g SP-36/tanaman), P3 $=150 \%$ (9 g SP36/tanaman) .

\section{Peubah Pengamatan}

Peubah vegetatif padi gogo yang diukur di antaranya: Tinggi tanaman (cm), Jumlah daun, Jumlah anakan per rumpun, jumlah anakan produktif per rumpun, Kandungan klorofil, dan Analisis Hara Tanaman. Peubah generatif padi gogo yang diukur di antaranya: Bobot 1000 benih (g), Jumlah gabah total per rumpun, Bobot gabah total per rumpun, Bobot gabah bernas per rumpun, Bobot gabah hampa per rumpun, dan Produktivitas Padi. Peubah pertumbuhan sengon gogo yang diukur di antaranya: Diameter Sengon, Pengukuran panjang akar, dan Tinggi pohon sengon. Peubah pendukung gogo yang diukur di antaranya: Analisis Tanah, Suhu dan Kelembaban, dan Pengukuran Intensitas Cahaya.

\section{HASIL DAN PEMBAHASAN}

\section{Pertumbuhan Sengon}

Pengamatan pertumbuhan sengon berupa tinggi pohon sengon, panjang akar sengon dan diameter sengon, dapat dilihat pada Tabel 1.

Tabel 1 Sidik ragam peubah pertumbuhan sengon (Paraserianthes falcataria $(\mathrm{L}$.$) Nielsen) (\mathrm{cm})$

\begin{tabular}{lcc}
\hline \multicolumn{1}{c}{ Peubah } & Agroforestri & Monokultur \\
\hline Tinggi Sengon & $160 \mathrm{a}$ & $140 \mathrm{~b}$ \\
$\begin{array}{l}\text { Diameter } \\
\text { Sengon }\end{array}$ & $3.32 \mathrm{a}$ & $1.29 \mathrm{~b}$ \\
$\begin{array}{l}\text { Panjang akar } \\
\text { Sengon }\end{array}$ & $27.60 \mathrm{a}$ & $15.70 \mathrm{~b}$ \\
\hline
\end{tabular}


Pola tanam secara agroforestri memiliki tinggi pohon sengon, panjang akar sengon dan diameter sengon lebih tinggi dibandingkan secara monokultur karena agroforestri terdapat input unsur hara makro dari pemupukan tanaman padi dibandingkan secara monokultur. Penanaman padi gogo agroforestri dapat memberikan dampak positif pada pohon sengon dengan kegiatan pemeliharaan, salah satunya adalah pemupukan. Penambahan pupuk sebagai suplai hara yang bertujuan untuk meningkatkan laju pertumbuhan padi gogo, diduga secara tidak langsung terserap oleh pohon sengon. Selain itu, kegiatan penyiangan dan pendangiran pada lahan agroforestri juga dapat meningkatkan kualitas tempat tumbuh pohon sengon (Senjaya 2017).

Berdasarkan data pengamatan diketahui bahwa ratarata pertambahan dimensi tinggi sengon pada lahan agroforestri dan monokultur adalah $1.47 \mathrm{~m}$ dan $0.90 \mathrm{~m}$ per 4 bulan. Rata-rata pertambahan diameter sengon pada lahan monokultur dan agroforestri Cikarawang adalah $1.57 \mathrm{~cm}$ dan $1.88 \mathrm{~cm}$ per 4 bulan (Senjaya 2017). Nusantara (2002) menyebutkan bahwa diameter sengon dapat bertambah karena suplai hara yang cukup dan lingkungan yang mendukung.

\section{Pertumbuhan dan Produksi Padi Gogo}

Hasil analisis sidik ragam terlihat bahwa perlakuan pola tanam, varietas dan pupuk berpengaruh nyata pada peubah jumlah anakan produktif, bobot gabah total per rumpun dan produktivitas padi, tetapi tidak berpengaruh nyata dalam peubah bobot gabah hampa per rumpun dengan perlakuan varietas (Tabel 2).

Intensitas cahaya rendah selama masa kritis yaitu masa vegetatif aktif dan fase generatif berpengaruh terhadap produksi padi. Chaturvedi et al. (1996) melaporkan bahwa intensitas radiasi rendah pada saat pembungaan dapat menurunkan karbohidrat yang terbentuk dan meningkatkan $\mathrm{N}$ yang larut dalam gabah, sehingga akan menyebabkan tingginya gabah hampa. Percobaan naungan pada masa bunting menyebabkan tingginya persentase steril pada padi hibrid, yang mungkin disebabkan oleh penghambatan fertilisasi yang berhubungan dengan rendahnya kemampuan polen (Ohtsubo, Kobayashi dan Shimazu 1993).

Suhu dan kelembaban dapat mempengaruhi pertumbuhan dan produksi padi gogo baik pola agroforestri maupun monokultur (Gambar 1).

Suhu udara yang optimal untuk pertumbuhan padi gogo adalah $20-35{ }^{\circ} \mathrm{C}$ sedangkan rata-rata kelembaban untuk kesesuaian pertumbuhan padi gogo adalah 33-90\% (Damanik 1989). Suhu berpengaruh langsung pada proses fotosintesis, respirasi,permeabilitas dinding sel, absorpsi air dan hara, transpirasi, aktivitas enzim dan koagulasi protein. Untuk pertumbuhan normal tanaman padi memerlukan lingkungan suhu dalam kisaran 20 sampai $35{ }^{\circ} \mathrm{C}$. Suhu dibawah $20{ }^{\circ} \mathrm{C}$ dan di atas $35{ }^{\circ} \mathrm{C}$ merupakan suhu kritis bagi tanaman padi (Yoshida 1981).

Kelembaban udara menggambarkan kandungan uap air di udara. Air adalah faktor yang lebih penting dalam produksi tanaman dibandingkan faktor lingkungan lainnya. Griffiths (1966) menyatakan bahwa air penting
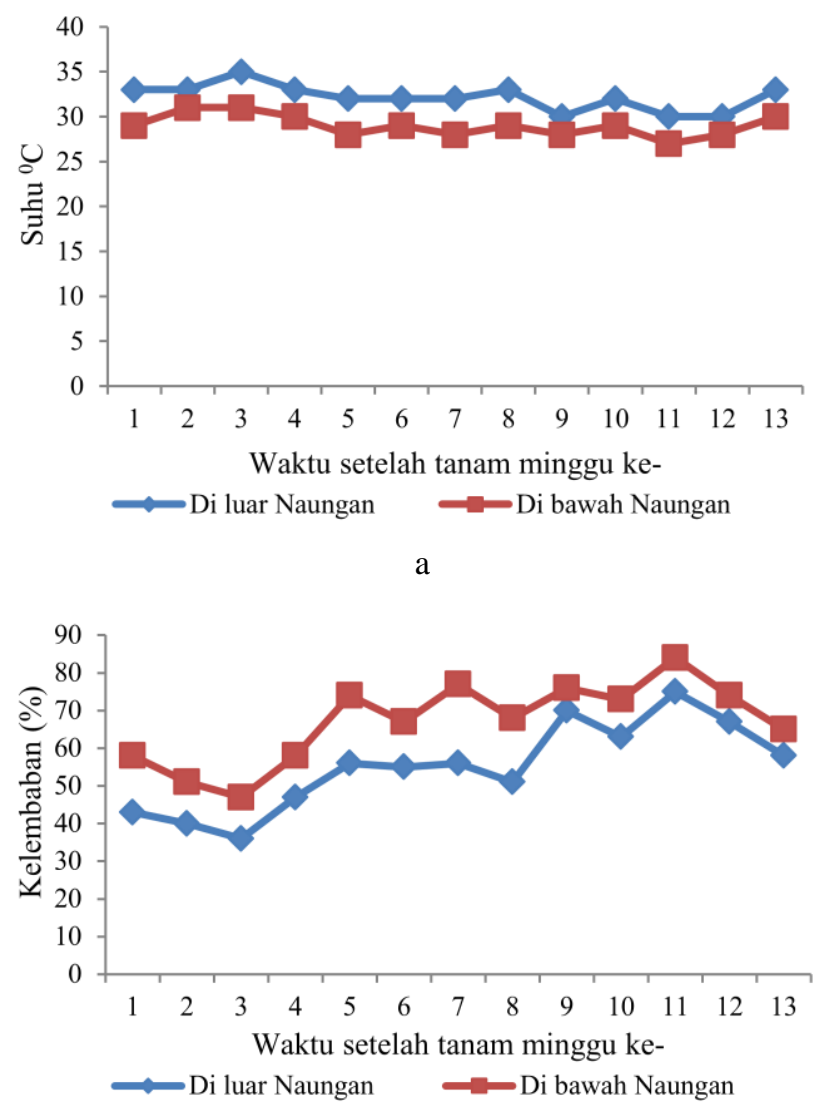

$\mathrm{b}$

Gambar 1 (a) Suhu udara dalam pola agroforestri dan pola monokultur, (b) Kelembaban dalam pola agroforestri dan pola monokultur

Tabel 2 Sidik ragam peubah produksi padi gogo (Oryza sativa L.)

\begin{tabular}{|c|c|c|c|c|c|c|c|}
\hline \multirow[b]{2}{*}{ Peubah } & \multicolumn{3}{|c|}{ Faktor tunggal } & \multicolumn{4}{|c|}{ Faktor interaksi } \\
\hline & Pola tanam & Varietas & Pupuk & $\begin{array}{l}\text { Pola tanam } \\
\text { dan } \\
\text { varietas }\end{array}$ & $\begin{array}{l}\text { Pola } \\
\text { tanam } \\
\text { dan } \\
\text { pupuk }\end{array}$ & $\begin{array}{l}\text { Varietas } \\
\text { dan } \\
\text { pupuk }\end{array}$ & $\begin{array}{l}\text { Pola } \\
\text { tanam, } \\
\text { varietas } \\
\text { dan pupuk }\end{array}$ \\
\hline $\begin{array}{l}\text { Jumlah anakan } \\
\text { produktif }\end{array}$ & $211.12 * *$ & $189.11 * *$ & $19.89 * *$ & $113.17 * *$ & 0.42 tn & $0.63 \mathrm{tn}$ & $4.35 * *$ \\
\hline $\begin{array}{l}\text { Bobot gabah total } \\
\text { per rumpun }\end{array}$ & $4876.21 * *$ & $3696.93 * *$ & $384.19 * *$ & $2957.79 * *$ & $17.12 * *$ & $\begin{array}{r}20.26 \\
* *\end{array}$ & $30.04 * *$ \\
\hline $\begin{array}{l}\text { Bobot gabah hampa } \\
\text { per rumpun }\end{array}$ & $34.30 * *$ & $0.67 \mathrm{tn}$ & $14.89 * *$ & $0.05 \mathrm{tn}$ & $3.68 *$ & $0.11 \mathrm{tn}$ & $0.16 \mathrm{tn}$ \\
\hline Produktivitas padi & $3004.82 * *$ & $2011.45 * *$ & $149.68 * *$ & $1426.77 * *$ & $6.65 * *$ & $9.00 * *$ & $3.48 *$ \\
\hline
\end{tabular}


karena dapat mengangkut unsur hara dari tanah ke akar dan diteruskan ke bagian-bagian tubuh tanaman lainnya. Proses fotosintesis akan menurun jika $30 \%$ kandungan air dalam daun hilang, kemudian proses fotosintesis akan terhenti jika kehilangan air mencapai $60 \%$.

Interaksi pola tanam, varietas dan pupuk pada peubah produkksi padi, dengan pola tanam secara monokultur dengan varietas sintanur dan pupuk $100 \%$ dengan hasil yang paling tinggi dibandingkan dengan interaksi yang lainnya (Tabel 3).

Penyerapan unsur $\mathrm{P}$ di dalam daun baik secara agroforestri maupun secara monokultur, pemupukan $\mathrm{P}$ 0\% sampai P 100\% mengalami peningkatan penyerapan unsur Pdidalam daun tetapi saat pemupukan ditingkatkan menjadi $\mathrm{P} 150 \%$, penyerapan $\mathrm{P}$ didalam daun menjadi berkurang.Efektivitas pemupukan fosfat anorganik pada tanah Ultisol hanya 10\%-30\%, sehingga 70\%-90\% pupuk $\mathrm{P}$ tetap berada di dalam tanah dan tidak dapat diserap tanaman (Jones 1982). Berdasarkan penelitian Barus (2005), pemupukan $100 \mathrm{~kg} \mathrm{P} / \mathrm{ha}$ berpengaruh terhadap peningkatan hasil panen dibandingkan dengan kontrol tetapi jika dosis pupuk ditingkatkan maka hasil panen akan menurun. Pada dosis $150 \mathrm{~kg} \mathrm{P} / \mathrm{ha}-200 \mathrm{~kg} \mathrm{P} / \mathrm{ha}$ hanya $5 \% \mathrm{P}-20 \% \mathrm{P}$ dapat diserap tanaman sehingga menimbulkan residu pupuk fosfat (Isgitani et al. 2005).

Varietas Sintanur memiliki produksi lebih tinggi dibandingkan varietas Situ Bagendit. Hal tersebut disebabkan varietas Sintanur memiliki jumlah anakan dan jumlah anakan produktif yang lebih banyak dibandingkan varietas Situ Bagendit sehingga banyak jumlah anakan tersebut dapat mengoptimalkan penyerapan intensitas cahaya yang dapat mengahasilkan asimilat berupa karbohidrat bagi produksi padi Sintanur.

Jumlah daun berkorelasi positif terhadap jumlah anakan maksimum dan jumlah anakan maksimum berkorelasi positif terhadap jumlah anakan produktif. Hal ini menunjukkan jumlah daun yang tinggi dapat meningkatkan jumlah anakan maksimum dan pada gilirannya dapat meningkatkan jumlah anakan produktif (Ete 2007).
Pada peubah vegetatif dan generatif padi memiliki hasil produktivitas yang tinggi pada pemupukan P 100\% dibandingkan dengan kadar pupuk $\mathrm{P}$ yang lain. Peningkatan terjadi pada klorofil daun dan kandungan $\mathrm{P}_{2} \mathrm{O}_{5}$ di dalam daun baik agroforestri maupun monokultur (Tabel 4).

Kandungan klorofil dan unsur $\mathrm{P}\left(\mathrm{P}_{2} \mathrm{O}_{5}\right)$ di dalam daun baik secara agroforestri maupun secara monokultur memiliki prosentase yang hampir sama. Hal tersebut dapat diduga karena daun yang ternaungi umumnya mempunyai klorofil lebih banyak, khususnya klorofil karena tiap kloroplas mempunyai lebih banyak grana daripada daun yang terbuka; Kloroplas pada daun yang ternaungi tersusun secara fototaksis dalam pola yang memaksimumkan penyerapan cahaya (Salisbury \& Ross 1992). Kloroplas daun yang ternaungi mempunyai protein stroma total lebih sedikit, termasuk enzim rubisco (Ribulosa-1.5-bisfosfat karboksilaseoksigenase) untuk menyatakan keterlibatan enzim tersebut dalam fiksasi $\mathrm{CO}_{2}$ dan $\mathrm{O}_{2}$ (Salisbury \& Ross 1992). Sulistiono et al. (1999) melaporkan terjadinya peningkatan kadar nitrogen daun dan nisbah klorofil b/a dengan meningkatnya intensitas naungan dari $0 \%, 25 \%$, $50 \%$ dan $75 \%$.

Dalam analisis tanah yang yang dilakukan sampel tanah dari lokasi penelitian, diperoleh tanah yang memiliki tekstur loam/lempung dan memiliki kandungan hara makro seperti $\mathrm{N}, \mathrm{P}$ dan $\mathrm{K}$ yang kriterianya sangat rendah dan rendah (Tabel 5). Tanahtanah entisol biasanya bertekstur pasir atau pasir berlempung dan kandungan bahan organik tanahnya rendah, sehingga kemampuannya menyimpan air tersedia juga rendah. Struktur, tekstur, dan ruang pori tanah juga mempengaruhi daya simpan air-tersedia. Kendala lahan kering pada tanah entisol adalah bentuklahan yang bergelombang hingga berbukit dengan tekstur berpasir sehingga rawan erosi, solum dangkal, kadar bahan organik rendah, miskin hara, kejenuhan basa rendah (Notohadiprawiro, 1989).

Mauro Wagner de Oliveira et al. (2002) menemukan bahwa permasalahan serius pada tanah-tanah berpasir

Tabel 3 Interaksi pola tanam, varietas dan pupuk p dalam pertumbuhan dan produksi padi gogo (Oryza sativa L.)

\begin{tabular}{|c|c|c|c|c|c|c|}
\hline & Perlakuan & & $\begin{array}{c}\text { Jumlah anakan } \\
\text { produktif } \\
\text { (anakan) }\end{array}$ & $\begin{array}{l}\text { Bobot gabah } \\
\text { total per } \\
\text { rumpun }(\mathrm{g})\end{array}$ & $\begin{array}{c}\text { Bobot gabah } \\
\text { hampa per } \\
\text { rumpun }(\mathrm{g})\end{array}$ & $\begin{array}{c}\text { Produktivitas } \\
\text { Padi (kg/ha) }\end{array}$ \\
\hline \multirow{8}{*}{$\begin{array}{l}\text { Agroforestri } \\
\text { (T1) }\end{array}$} & Situ Bagendit (V1) & $\mathrm{P} 0 \%$ & $5 \mathrm{f}$ & $16.08 \mathrm{j}$ & $1.65 \mathrm{a}$ & $2573.12 \mathrm{j}$ \\
\hline & & P $50 \%$ & $6 \mathrm{ef}$ & $18.06 \mathrm{hi}$ & $1.15 \mathrm{a}$ & $2890.88 \mathrm{hi}$ \\
\hline & & P $100 \%$ & $7 \mathrm{de}$ & $22.45 \mathrm{f}$ & $0.96 \mathrm{a}$ & $3591.96 \mathrm{e}$ \\
\hline & & P $150 \%$ & $7 \mathrm{de}$ & $20.03 \mathrm{~g}$ & $1.21 \mathrm{a}$ & $3206.08 \mathrm{f}$ \\
\hline & Sintanur (V2) & Р $0 \%$ & $6 \mathrm{de}$ & $17.46 \mathrm{i}$ & $1.65 \mathrm{a}$ & $2794.88 \mathrm{i}$ \\
\hline & & P $50 \%$ & $7 \mathrm{de}$ & $19.58 \mathrm{~g}$ & $1.03 \mathrm{a}$ & $3133.12 \mathrm{fg}$ \\
\hline & & P $100 \%$ & $7 \mathrm{de}$ & $22.75 \mathrm{f}$ & $0.93 \mathrm{a}$ & $3640.64 \mathrm{e}$ \\
\hline & & P $150 \%$ & $7 \mathrm{de}$ & $21.89 \mathrm{f}$ & $1.13 \mathrm{a}$ & $3503.36 \mathrm{e}$ \\
\hline \multirow{8}{*}{$\begin{array}{l}\text { Monokultur } \\
\text { (T2) }\end{array}$} & Situ Bagendit (V1) & P $0 \%$ & $6 \mathrm{de}$ & $18.92 \mathrm{gh}$ & $1.02 \mathrm{a}$ & $3027.52 \mathrm{gh}$ \\
\hline & & P $50 \%$ & $7 \mathrm{de}$ & $22.91 \mathrm{f}$ & $0.91 \mathrm{a}$ & $3666.88 \mathrm{e}$ \\
\hline & & P $100 \%$ & $7 \mathrm{de}$ & $25.07 \mathrm{e}$ & $0.77 \mathrm{a}$ & $4011.84 \mathrm{~d}$ \\
\hline & & P $150 \%$ & $7 \mathrm{~d}$ & $21.91 \mathrm{f}$ & $0.97 \mathrm{a}$ & $3506.56 \mathrm{e}$ \\
\hline & Sintanur (V2) & $\mathrm{P} 0 \%$ & $10 \mathrm{c}$ & $35.28 \mathrm{~d}$ & $1.01 \mathrm{a}$ & $5645.44 \mathrm{c}$ \\
\hline & & P $50 \%$ & $11 \mathrm{~b}$ & $36.40 \mathrm{c}$ & $0.93 \mathrm{a}$ & $5824.00 \mathrm{~b}$ \\
\hline & & P $100 \%$ & $15 \mathrm{a}$ & $38.29 \mathrm{a}$ & $0.72 \mathrm{a}$ & $6126.40 \mathrm{a}$ \\
\hline & & P $150 \%$ & $14 \mathrm{a}$ & $37.96 \mathrm{~b}$ & $0.93 \mathrm{a}$ & $6073.60 \mathrm{a}$ \\
\hline
\end{tabular}


adalah tingginya pencucian hara pupuk. Menurut hasil penelitian Tangkoonboribun (2007), kendala utama yang dihadapi oleh budidaya tebu pada tanah-tanah berpasir adalah rendahnya kandungan bahan organik tanah dan kandungan P-tersedia.

Hardjowigeno (1992) bahwa warna tanah berfungsi sebagai penunjuk dari sifat tanah, karena warna tanah dipengaruhi oleh beberapa faktor yang terdapat dalam tanah tersebut. Penyebab perbedaan warna permukaan tanah umumnya dipengaruhi oleh perbedaan kandungan bahan organik. Makin tinggi kandungan bahan organik, warna tanah makin gelap. Sedangkan dilapisan bawah, kandungan bahan organik umumnya rendah, warna tanah banyak dipengaruhi oleh bentuk dan banyaknya senyawa Fe dalam tanah.

$\mathrm{pH}$ tanah menjadi rendah akibat pemupukan secara berlebih sehingga dapat menjadi racun bagi tanaman maupun tanah dan mengakibatkan tanah menjadi asam. Menurut Lestari (2009) terjadinya pemasaman tanah dapat di akibatkan oleh pupuk nitrogen buatan secara terus menerus dalam jumlah besar.

\section{SIMPULAN DAN SARAN}

\section{Simpulan}

Sistem agroforestri dengan penanaman padi gogo baik varietas Sintanur dan Situ Bagendit dengan berbagai taraf pemupukan $\mathrm{P} \quad 0 \%-150 \%$ dapat meningkatkan pertumbuhan sengon dibandingkan monokultur. Penggunaan padi gogo varietas Sintanur memiliki produksi lebih tinggi dibandingkan varietas Situ Bagendit. Padi gogo varietas Sintanur dengan monokultur memiliki hasil produksi 1.5 kali lebih tinggi dibandingkan agroforestri. Pemupukan P 100\% (6 g SP36/tanaman) pada tanaman padi gogo baik agroforestri dan monokultur dengan varietas Sintanur dan Situ Bagendit menghasilkan produksi padi gogo yang lebih tinggi dibandingkan taraf pemupukan P 0\%, P 50\% dan P $150 \%$. Pemupukan P $100 \%$ dengan padi gogo varietas Sintanur dan sistem monokultur memiliki hasil produksi padi gogo lebih baik dibandingkan sistem agroforestri dan varietas Situ Bagendit yaitu 6126.40 $\mathrm{kg} / \mathrm{ha}$.

Tabel 4 Kandungan Klorofil dan Unsur P di dalam daun padi gogo (Oryza sativa L.)

\begin{tabular}{llllll}
\hline \multirow{2}{*}{ No. } & Jenis Sampel & \multicolumn{2}{l}{ Klorofil Daun $(\mathrm{mg} /$ gr FreshWeight) } & $\mathrm{P}_{2} \mathrm{O}_{5}$ Daun $(\%)$ & Monokultur \\
\cline { 3 - 6 } & & Agroforestri & Monokultur & Agroforestri & \\
\hline 1. & Situbagendit P 0\% & 2.242 & 2.529 & 0.194 & 0.114 \\
2. & Situbagendit P 50\% & 2.219 & 2.809 & 0.160 & 0.181 \\
3. & Situbagendit P 100\% & 3.405 & 2.914 & 0.395 & 0.357 \\
4. & Situbagendit P 150\% & 2.329 & 2.841 & 0.253 & 0.249 \\
5. & Sintanur P 0\% & 1.796 & 1.958 & 0.063 & 0.043 \\
6. & Sintanur P 50\% & 2.856 & 2.353 & 0.278 & 0.104 \\
7. & Sintanur P 100\% & 3.170 & 3.017 & 0.366 & 0.347 \\
8. & Sintanur P 150\% & 2.314 & 2.861 & 0.253 & 0.285 \\
\hline
\end{tabular}

(Data Sekunder Politeknik Jember 2017)

Tabel 5 Parameter sifat fisik tanah dan kimia tanah

\begin{tabular}{|c|c|c|c|c|c|}
\hline \multirow[t]{3}{*}{ Jenis analisis } & \multicolumn{4}{|c|}{ Hasil analisis } & \multirow{3}{*}{$\begin{array}{l}\text { Tingkat nilai sifat } \\
\text { kimia tanah }\end{array}$} \\
\hline & \multicolumn{2}{|c|}{ Sebelum penanaman padi } & \multicolumn{2}{|c|}{ Setelah penanaman padi } & \\
\hline & Agroforestri & Monokultur & Agroforestri & Monokultur & \\
\hline $\begin{array}{l}\text { Parameter Fisi } \\
\text { Pasir }\end{array}$ & & & & & \\
\hline Liat & $\begin{array}{l}49.93 \% \\
15.84 \%\end{array}$ & $\begin{array}{l}49.93 \% \\
15.84 \%\end{array}$ & & - & \\
\hline Debu & $34.23 \%$ & $34.23 \%$ & & & \\
\hline Tekstur & $\begin{array}{l}\text { Loam } \\
\text { (Lempung) }\end{array}$ & $\begin{array}{l}\text { Loam } \\
\text { (Lempung) }\end{array}$ & - & & \\
\hline Kadar Air & $31.274 \%$ & $31.445 \%$ & $36.265 \%$ & $30.796 \%$ & \\
\hline $\begin{array}{l}\text { Parameter } \\
\text { Kimia }\end{array}$ & & & & & $\begin{array}{l}\text { Rendah dan sangat } \\
\text { rendah }\end{array}$ \\
\hline N-Total & $0.102 \%$ & $0.082 \%$ & $0.100 \%$ & 0.090 & \\
\hline $\mathrm{P}_{2} \mathrm{O}_{5}$ & $18.9 \mathrm{ppm}$ & $16.8 \mathrm{ppm}$ & $16.012 \mathrm{ppm}$ & $12.877 \mathrm{ppm}$ & Sedang dan tinggi \\
\hline $\mathrm{pH}$ & 7.07 & 6.09 & 6.6 & 6.8 & Tinggi dan sedang \\
\hline $\mathrm{K}_{2} \mathrm{O}$ & 79 ppm & 43 ppm & $1.521 \mathrm{ppm}$ & $0.474 \mathrm{ppm}$ & Rendah \\
\hline C-organik & Tidak diukur & Tidak diukur & $1.853 \%$ & $1.437 \%$ & Rendah \\
\hline $\mathrm{C} / \mathrm{N}$ rasio & Tidak diukur & Tidak diukur & $18.618 \%$ & $16.174 \%$ & \\
\hline KTK & Tidak diukur & Tidak diukur & $19.9 \mathrm{Cmol} / \mathrm{Kg}$ & $21.4 \mathrm{Cmol} / \mathrm{kg}$ & \\
\hline
\end{tabular}




\section{Saran}

Penanamana padi gogo varietas Sintanur dan Situ Bagendit serta taraf pupuk $\mathrm{P}$ dengan agroforestri dapat meningkatkan pertumbuhan sengon. Penggunaan padi gogo varietas Sintanur dengan agroforestri dan monokultur memiliki hasil produksi lebih tinggi dibandingkan padi gogo varietas Situ Bagendit. Pemupukan P $100 \%$ pada padi gogo varietas Sintanur dengan monokultur memiliki hasil produksi yang lebih tinggi dibandingkan pemupukan taraf $\mathrm{P}$ yang lain.

\section{DAFTAR PUSTAKA}

Barus J. 2005. Respon tanaman padi terhadap pemupukan $\mathrm{P}$ pada tingkat status hara $\mathrm{P}$ tanah yang berbeda. Jurnal Akta Agrosia. 8:52-55.

Chaturvedi GS, Ram PC, Singh AK, Ram P, Ingram KT, Singht RK, Sing VP. 1996. Carbohydrat status of rainfed lowland rices in relation to submergeed, drought and shade. In Proceeding Physiology of stress tolerance in rice. 104-122.

Damanik BSJ. 1989. Pertumbuhan dan hasil tanaman padi gogo pada berbagai perlakuan agronomis [tesis]. Bogor (ID): Institut Pertanian Bogor.

[Deptan] Departemen Pertanian. 2008. Pengelolaan Tanaman Terpadu (PTT) Padi Gogo. Jakarta (ID): Departemen Pertanian.

Ete A. 2007. Studi fisiologi dan identifikasi protein fotosintetik padi gogo toleran naungan [disertasi]. Bogor (ID): Institut Pertanian Bogor.

Fadiluddin M. 2009. Efektivitas formula pupuk hayati dalam memacu serapan hara, produksi dan kulaitas hasil jagung dan padi gogo di lapang [tesis]. Bogor (ID): Institut Pertanian Bogor.

Griffiths JF. 1966. Applied Climatology. New York (US): Oxford University Press.

Hafsah S, Zuyasna. 2013. Uji patogenisitas beberapa isolasi penyakit busuk buah kakao asal Aceh dan evaluasi efektivitas metode inokulasi. Jurnal Agrista. 17(1):42-48.

Hardjowigeno S. 1992. Ilmu Tanah. Edisi ketiga. Jakarta (ID): PT. Mediyatama Sarana Perkasa.

Hartoyo APP. 2014. pertumbuhan dan produksi kedelai (Glycine $\max (\mathrm{L}$.$) Merrill) berbasiskan agroforestri$ sengon (Paraserianthes Falcataria (L.) Nielsen) [tesis]. Bogor (ID): Institut Pertanian Bogor.

Irpan MA. 2011. Respon tanaman kedelai dan padi gogo terhadap limbah budi daya jamur tiram [tesis]. Bogor (ID): Institut Pertanian Bogor.

Isgitani M, Kabirun S, Siradz SA. 2005. Pengaruh inokulasi bakteri pelarut fosfat terhadap pertumbuhan shorghum pada berbagai kandungan P tanah. Jurnal Ilmu Tanah dan Lingkungan. 5:4854.

Jones US. 1982. Fertilizer and Soil Fertility. Second edition. Virginia (US): Reston Publ.

Junaedi A. 2001. Studi kehampaan dan kandungan karbohidrat pada padi gogo toleran naungan [tesis]. Bogor (ID): Institut Pertanian Bogor.
Khalif U, Utami SR, Kusuma Z. 2014. Pengaruh Penanaman Sengon (Paraserianthes falcataria) Terhadap Kandungan $\mathrm{C}$ dan $\mathrm{N}$ Tanah di Desa Slamparejo, Jabung, Malang. Jurnal Tanah dan Sumberdaya Lahan. 1 (1): 9-16.

Lautt BS. 2003. Fisiologi toleransi padi gogo terhadap naungan: tinjauan karakteristik fotosintesis dan respirasi [Disertasi]. Bogor (ID): Institut Pertanian Bogor.

Lestari Y. 2014. Pengaruh letak pemberian pupuk NPK terhadap pertumbuhan akar semai sengon (Paraserianthes falcataria (L.) Nielsen) [Skripsi]. Bogor (ID): Institut Pertanian Bogor.

Nusantara AD. 2002. Tanggapan semai sengon (Paraserianthes falcataria (L.) Nielsen) terhadap inokulasi ganda cendawan mikoriza arbuskular dan Rhizobium sp. Jurnal Ilmu-Ilmu Pertanian Indonesia 4(2):62-70.

Ohtsubo K, Kobayashi A, Shimizu H. 1993. Quality evolution of rice in Japan. Japan Agric. Res. Quart. 27: 95 - 101.

Putra S. 2011. Pengaruh jarak tanam terhadap peningkatan hasil padi gogo varietas Situ Patenggang. Agrin. 15 (1) : $54-63$.

Salisbury FB, Ross CW. 1992. Fisiologi Tumbuhan Jilid II. Bandung (ID): Penerbit ITB.

Santosa E. 2000. Adaptasi fisiologi tanaman padi gogo terhadap naungan: laju pertukaran karbon, respirasi dan konduktansi stomata [tesis]. Bogor (ID): Institut Pertanian Bogor.

Saragih JF. 2005. Pengaruh inokulasi cendawan mikoriza arbuskular (CMA), fosfor, dan silika terhadap pertumbuhan padi gogo pada ultisol jasinga [skripsi]. Bogor (ID): Institut Pertanian Bogor.

Senjaya N. 2017. Evaluasi sistem agroforestri sengon (Paraserianthes falcataria (L.) Nielsen) dengan padi gogo (Oryza sativa L.) [tesis]. Bogor (ID): Institut Pertanian Bogor.

Sulistiono E, Sopandie D, Chozin MA, Suwarno. 1999. Adaptasi padi gogo terhadap naungan : pendekatan morfologi dan fisiologi. Comm. Ag. 4(2): 62-68.

Van Noordwijk M, Coe R, Sinclair F. 2016. Central hypotheses for the third agroforestry paradigm within a common definition. Bogor (ID): World Agroforestry Centre (ICRAF) Southeast Asia Regional Program.

Wijayanto N, Pratiwi E. 2011. Pengaruh naungan dari tegakan sengon (Paraserianthes falcataria (L.) Nielsen) terhadap pertumbuhan tanaman porang (Amorphophallus onchophyllus). Silvikultur Tropika. 2(1): 46-51.

Winarso S. 2005. Kesuburan Tanah, Dasar Kesehatan dan Kualitas Tanah. Yogyakarta (ID): Gava Media.

Yoshida. 1981. Fundamentals of Rice. Los Banos. Philippines (PH): Crop Science. IRRI. 